\title{
The Views of Educators and Thinkers Who Influenced Education Policies in the Ottoman Period
}

\author{
Ethem Gürhan (Corresponding author) \\ Ahmet Keleşoğlu Eğitim Fakültesi \\ Necmettin Erbakan Üniversitesi, Meram-Konya 42090, Turkey \\ E-mail: ethem.gurhan@ogr.erbakan.edu.tr \\ Sabahattin Çiftçi \\ Ahmet Keleşoğlu Eğitim Fakültesi \\ Necmettin Erbakan Üniversitesi, Meram-Konya 42090, Turkey \\ E-mail: sciftci@konya.edu.tr
}

$\begin{array}{lc}\text { Received: February 9, } 2021 & \text { Accepted: March 12, } 2021 \quad \text { Published: March 21, } 2021 \\ \text { doi:10.5296/jei.v7i1.18290 } & \text { URL: https://doi.org/10.5296/jei.v7i1.18290 }\end{array}$

\begin{abstract}
Intellectuals and thinkers, who are influential on the society, have an influence on the people they live with their ideas, especially on the growing generations. It is seen that this intelligentsia, who leads and guides the society they live in, deeply affects the life of society. The works of these people, who have important roles in shaping the society in which they live with their thoughts, are adopted by the individuals in that society and their influence on the generation that has grown for many years is seen to last. The works of these people adopted by the society and their thoughts in these works are shown as examples in the educational institutions of that society and read as textbooks. For this reason, the opinions of educators and thinkers in that society have an impact on the growing generation.

Surely, when we look at the Ottoman period, the number of educators and thinkers who had an impact on society is quite high. However, it is not possible to address all of them. That is not the point of this research. The important criterion in this research is the most important educators and thinkers of each period. In particular, they are educators and thinkers who have basic works on education and whose works have been taught in schools as textbooks for many years, and who have significant effects on social life. When we look at these thinkers, we can see that their influence continues from past to present. In this research, the document
\end{abstract}


review pattern, which is one of the qualitative research methods, was used and it was determined that the findings of the research were dominated by the view that educational policies based on moral values and aiming to be trained in line with the abilities of the student should be applied in the ottoman period human education policies. In addition, it is seen that the first step of physically transitioning from madrasa system to today's modern school and classroom system was taken by Selim Sabit Efendi.

Keywords: Ottoman educators, Education in Ottoman, Views of Ottoman educators

\section{Introduction}

Education problem has been one of the main problems of all societies from past to present. The future of that society, which keeps a society alive and enables it to reach the level of advanced civilizations, depends on the education of its children. Likewise, a solid human education is the basis of being a strong state. The education systems of developed societies are always shown as an example and their education is aimed.

The reason why the education system and human education policies in the Ottoman Empire has been the subject of research is that it had survived for centuries and was one of the powerful states of its time. It is the common goal of us educators to provide the best education to our children to whom we will entrust our future and our country. Therefore, the opinions of the best educators and thinkers of the period who lived in the Ottoman Empire on education have been the subject of the study. Based on these views, the results of the research will shed light on the problems of education, which is currently a serious problem.

Purpose of the Study: The purpose of this research is to reveal the views of the main educators and thinkers who were influential in the educational policies of the Ottoman Empire, a powerful state that had existed for centuries, and the research questions are as follows:

(1) What are Sâdi Shirazi's views on education?

(2) How are Kınalıâde Ali Efendi's views on education?

(3) What are Nâbi's views on education?

(4) What are Ali Suavî’s views on education?

(5) What are the views of Emrullah Efendi on education?

(6) What are Selim Sabit Efendi's views on education?

(7) What are Satı Bey's views on education?

\section{Method}

The method of this research is the document analysis method, which is one of the qualitative research methods. In document analysis, the researcher can obtain the data he needs by saving time and money without interviewing or observing (Yıldırım \& Şimşek, 2011). Document review can be done in five stages: (1) Accessing documents, (2) checking its 
originality, (3) understanding documents, (4) analyzing data, (5) using data (Forster, 1995).

\section{Literature Review}

In this section, information obtained from documents related to the subject is shared.

\subsection{Sâdi Shirazi (1184-1276)}

Sâdi is one of the great poets of Iran. His work Bostan and Gülistan has a very important place in the history of Turkish education. His books, which focus on discipline and moral methods, reveal the basic criteria of attitudes and behaviors that should be brought to the generations from the thirteenth century to the present. It is seen that Bostan and Gülistan influenced many statesmen as well as Turkish thinkers and writers. In addition, it has been among the basic textbooks of school and madrasah students until recently. The grown generations were raised according to the teachings in these works (Kurnaz, 1984).

Before writing his works, he visited many places and "received a spike from each blend". His long-term travels made him a thinker who was tolerant, who knew people and nature well, who loved them, and brought a universal quality to his ideas. He gives examples of the Quran and hadiths in his works. Because, he is also a Sunni and religious artist. However, he also strongly opposes hypocrite religionist and disapproves of excess in worship. He sees the good deeds as superior to worship (Akyüz, 1993).

Sâdi's views on education generally have universal Islamic characteristics. However, it is seen that he does not express his views meticulously and sprinkles them all over his works. In other words, in his work Bostan and Gülistan, we do not encounter a systematic that we expect in terms of education. Because it was not written directly for this purpose. It is a work of art despite its more educational characteristics. However, it contains very rich information about recognition, education and directing of human.

It is seen that Sâdi concentrates his views on three main issues. They are like educational views about the daily life and general behavior of the individual, their views on education and political views.

\subsubsection{Views on Child Education}

Sâdi focuses more on the education of children entering the puberty period (due to the age of 10), and by putting forward their judgment abilities recommends that children be brought up firstly with "knowledge", "skills" and "ingenuity".

He puts forward the following views on the method to be applied in child education and the teacher's behavior that has a role in the upbringing of the child: The child should not be given to a bad teacher, otherwise the child will be like the teacher himself. In order not to intimidate the beginners of the school and not to alienate them from education, the teacher should approach the children with compassion and nice words in a way that they like. After the child gets used to the school, the teacher should represent the authority. Otherwise, the child will not listen to his teacher, he will be spoiled and undisciplined. Children should not fail to respect their teachers. Not all children in the hands of a good teacher grow up to the same 
extent. Sâdi explains this situation with "difference in abilities".

The father should not raise his children in a kind and coy way, otherwise the child will be overwhelmed by the difficulties of life. The child should be taught from a young age. When they do good things, they should be rewarded and encouraged, and when they do bad things they should be punished. However, one should be moderate in reward and punishment (Sâdi, 1975).

\subsubsection{Educational Views on Life and General Behaviors of the Person}

The individual is obliged to act according to some rules in order to be happy in society. These rules are specified in detail. Some of the important ones among these are; speaking timely and in moderation, knowing how to speak and be quiet, speaking correctly, acting "measuredly" at various stages of daily life, such as at the table, in the guest house, on the street, in the family, in the relationship with the elderly and the elderly, and following the rules of decency. We can say that the views on the general behavior of the individual in Bostan and Gülistan had been adopted for centuries as etiquette in the old life of Turks. His views on children's upbringing also left deep and continuous traces, but the issue of beatings in education has lost its validity today. Because punishment prevents learning at the rate that the reward increases learning. Learning with fear is not continuous.

\subsubsection{Political Ideas}

In this area, Sâdi expresses his views on the attitude and behavior of the ruler, his views on politics, military service, and state administration. According to Sâdi, power should be based on the people, integrate with the people and take its power from the people. The ruler who manages the state must be devout, fair and generous to his people (Sadi, 1975).

\subsection{Kinalızâde Ali Efendi (1510-1572)}

Kınalızâde Ali Efendi, who was a professor at the Süleymaniye madrasa and also a judge in Cairo, Bursa and Istanbul, is one of the greatest philosophers the Ottomans raised. He has a rightful reputation with his work Ahlâk-1 Alaî in the field of practical philosophy, which the ancients called hikmet-i ameli. Ahlâk-1 Alaî is also the first of the ethics books written in Turkish. This book was the source of moral lessons in madrasahs and civil schools until the last years of the empire (Kınalıâde, n.d.a).

According to Kinalıâde Ali Efendi; the way to be a good person is possible with a good education. He emphasizes that moral people will be happy in the world and the hereafter. He is optimistic about moral education. According to him, education has an important place in the training of people. Ahlâk-1 Alâî consists of three works of ethics, family ethics and state ethics:

\subsubsection{Moral Science}

In the first book titled moral science the following topics are discussed and examined. They are the concepts of human spirit, morality and temperament, which are called nefs-i natika, the issue of whether they will change through discipline, wisdom, courage, chastity and 
justice, ignorance, cowardice, unchastity and cruelty, the remedy of mental illness, fear of death, lust, stinginess and generosity concepts (Kınalıâde, n.d.a).

In the science of ethics, the author speaks of practical morality, which he calls amel-i hikmet (deed wisdom). He says: "One can remove his faults by looking at bad people and avoiding what they do. Lokman Hekim said that I learned decency from immoral people because I did not do what they did. Those who seek virtue should definitely avoid being arrogant, should not be proud and know themselves (Ülken, 1967).

\subsubsection{Family Ethics}

In this section, the establishment of the family, the duties and responsibilities of the spouses towards each other, and the training methods of the children are emphasized. After pointing out the religious, moral, social, political and economic factors that make the family permanent and happy, Kınalizâde Ali Efendi pointed out that multiple marriage is an issue that disrupts the order of the family and eliminates happiness (Kınalızâde, n.d.b). Thus, he defended monogamy that is valid today four centuries ago. Kınalıâde Ali Efendi, who overemphasizes child education, explains the principles of child upbringing as follows:

It prescribes three training periods for the child: natural, suggestive and voluntary. In each of these periods, attention is paid to how the child should be treated and what should be given to the child. He draws attention to the qualities that should be found in the duenna and the teacher regarding child education. He grounds on the nature of the child in his/her education. After all this, he suggests that the child should study in the field of which he/she is gifted or choose an art. In this respect, it is possible to say that there is not much difference between these views on child upbringing in the tenth century and the issues predicted by today's pedagogical data (Esen, 1991). Whether a boy or a girl, when it is born, the parents should be thankful to Allah and they should know that it is a divine gift. A good name should be given to it, a healthy body and mind, and a moral milk mother should be found. The child's friends must be good because his temperament and behavior are quickly shaped by what he sees in his friends. As the Prophet said, he should be ordered to pray at the age of seven, and if he does not do this at the age of ten, he should be slightly beaten. The boys should be imbued with the view that dressing in a gaudy way is womanish. Natural habits such as lying and theft in children should be corrected immediately. Even the children of the monarch should not be raised gently. The child should not be fed too much in the morning, because this prevents him from learning his/her lessons. The child should be taught how to walk, ride a horse, sit, stand up, eat; speaking etiquette, and also art. The teacher should be wise, devout, good, moderate in his anger and gentleness. If he/she is too angry, the child will be sad and as a result he hates learning. However, the teacher should not be too soft to do his/her job of training and refinement. The teacher may use moderate beating as and when required. The child should be accustomed to generosity and learn to help friends. He should be allowed to play some games every day, but these should not be improper and bad things. He/she should be directed according to his/her abilities, and his time should not be wasted by working in areas that are not capable and relevant. In addition to what has been said, it provides some additional information in the education of girls. While emphasizing that girls should also be 
given a proper education, they should be given more information about life, chastity, the avoidance of boys, the sense of shame, and housework. Contrary to what some Muslim writers said at that time, he says that girls should read and write (Kınalızâde, n.d.b; Akyüz, 1993; Öztürk, 1991). Considering that this issue has not been completely resolved in our country even today, it will be revealed by itself how a far-forward thinker Kınalızâde Ali Efendi is.

\subsubsection{State Ethics}

The ethic of the state has the characteristics of a political treatise and has brought together the traditional Islamic management principles (Akyüz, 1993). According to Kınalızâde Ali Efendi, just as the body is based on the soul and the soul on the mind, the state is based on politics and politics on wisdom. Everyone, from the head of state to a simple citizen, has a duty and responsibility in this regard. In addition, the spirit of love, solidarity and justice, one of the fundamental values of social life, should be developed, and tightly clung to the social structure so that a life style worth living can emerge ... (Kinalızâde, n.d.b). When we evaluate Kınalıâde Ali Efendi's views in today's education system, we can see that many criteria are still valid.

\subsection{Nâbi (1642-1712)}

Considered one of the important representatives of didactic (instructive) poetry in Divan literature, Nâbi wrote a poetic work called "Hayriyye" (1701) to give advice to his son. These advices have been approved and adopted over time for all children. Nâbi's works were read and memorized by intellectuals until the Republic period, and children were tried to be raised in line with Nâbi’s thoughts (Akyüz, 1993).

Nâbi regards his style of behavior as the qualities of an acceptable person who is self-contained, not only cultured, but also insensitive to social issues, disconnected from the outside world, and who does not think anything but comfort. For this reason, the human type he describes is the "average person" type. When we look at the ancient Turkish history, the "alpine type" created by the nomadic equestrian civilization described in the epics is extremely active and extroverted. This type, which has the will to dominate the world, became a "veteran type" after Islam and played a major role in the formation of the Seljuk and Ottoman states.

While the alpine and veteran types have demonstrated the most distinctive characteristics of the Turks throughout history in terms of extroversion, activity and social responsibility awareness, care was taken to raise children according to these criteria. These criteria are nothing but the modern human type that all societies in the world aim at (Kaplan, 1995). When we look at Nâbi's life philosophy, we see that instead of the alpine human type, there is a fatalist type of human being. Nâbi, who is an urban type and lives in the city, sees life and the universe as a complete urbanite. According to Nâbi, the universe is a bazaar and the law of scales, that is, have the full knowledge of the principle of balance between contrasts. In this regard, Nâbi advises his son to be a "average person". According to him, a person can only find comfort by worshiping Allah, consenting to everything that happens to him and not 
setting his sights high. This type is an average type of person who is taken to his own corner, is content with little, does not interfere with anything, and thinks only to save himself and his own comfort (Mengi, 1991).

What influenced the formation of these views in Nâbi can be explained by the management style of the period. There is no doubt that such a type of human emerged from the stagnating and regressing social and political life of the period. Nâbi draws a type of person who has been subjected to injustice and tyranny, who is not able to do anything against them, retreats to a corner and is patient, clinging to religion more, looking for a minimum peace for himself and presents this as the type to be exemplified. However, it is seen that these views stemming from the political and social breakdowns of that period were effective in the passive upbringing of later generations.

\subsection{Ali Suavî (1839-1878)}

Ali Suavî is one of the writers who had an important place in the history of Turkish thought and culture during the westernization period. He is a well-educated but mostly self-taught intellectual and highbrow. He focuses on the educational problems of the period. He argues that the education system of the madrasa is behind the age and opposes the educational understanding of the madrasa. He asserts that madrasahs neutralize people with the eastern culture and theoretical knowledge that are not useful in practice, instead of the trained manpower needed by the society. For him, the period is the age of industry and information. People can gain their place in the information age with modern educational understanding and practices. Instead of madrasah teaching, which takes a long period of 15 years, he wants people to be given the necessary information in a period of 4-5 years, as in the west. It is without being tired of the education that people have received from wasting time that they will start life as active and well-informed at a younger age. He prefers an active person equipped with essential knowledge, rather than a passive person equipped with a lot of unnecessary information.

Another initiative of Ali Suavî that went down in the history of Turkish education is to send his newspaper to schools free of charge (Akyüz, 1993). Considering this situation as a requirement of today's modern understanding of education, it can be regarded as an evidence of how advanced Ali Suavî's views and wit are. According to him, one should grow up as open to different ideas and views, not with a one-sided idea. He should be well-informed, foresighted, active, but never forget the culture that generated his egoity. Because while cultural values reveal the reason for the existence of that society, it also enables the development of science. No culture without knowledge, no science without culture. The purpose of educational theories are to protect and develop these two important factors in society. Educational institutions should be developed by taking these factors into consideration and by renewing their programs in line with the needs of the society. Ali Suavî also worked on the Turkish language and Turkish history, and became the leader of Turkism with his views. His views on this issue are gathered mainly on the following three principles; The Turkish race is the most superior and oldest race in terms of its military, civil and political effects. 
Turkish language is the richest, most advanced and most mature language in the world. The Turkish race has served the cultural history the most and has made great contributions especially in the formation of Islamic culture. According to him, Turks are the biggest nation that makes history on earth (Çubukçu, 1991). For this reason, generations should be raised with Turkish culture.

Ali Suavî, like the other New Ottomans, takes his social and political ideas from the religion of Islam. He accepts monarchy as a political regime, however, the monarchy is understood as despotism and strongly opposed to the leaders seeing themselves above the laws (Çelik, 1993). According to him, the government should take its power from the people but it should be governed by Islamic rules. Young people should also be raised as good Muslims according to these criteria.

\subsection{Emrullah Efendi (1858-1914)}

Emrullah Efendi, who graduated from the Civil School, worked as a teacher in Darülfünun and was the minister of education during the 2nd Constitutional Monarchy. His articles on education were published in various newspapers and especially in the "Servet-i Fünun" magazine.

Emrullah Efendi symbolizes a transition period in education. According to him, in human nature, there is a desire and interest to know the Creator, to do good and to hear beauty. Education is a set of measures to develop all these in harmony. In a circular he issued on the day he was minister, he addressed the teachers as follows:

"As a teacher and an educator, you have a rare job in the country. In order to ensure the future's well-being and the rise of the Constitutional Monarchy, the children of the country should be raised in accordance with the constitutionalism with moral and mental education "(Binbaşıŏlu, 1995). Emrullah Efendi draws attention in education with his view known as the "Tuba Tree (Ailanthus) Theory". According to this view; for the development of a country, innovation in education should be started from higher education, not primary education. Developments in higher education are gradually reflected in secondary education and then in primary education and finally spread to the whole country. Like Tuba Tree (Ailanthus), which is believed to exist in Paradise, the roots of education are above and its branches are below. Our education can also be developed from top to bottom. Because it is necessary to establish and develop a scientific mindset first. Darülfünun can do that too. According to him, the evolution of humanity was achieved by developing the sciences in universities (Akyüz, 1993). Emrullah Efendi tried to explain the necessity of primary education in terms of children's rights and stated that the history of the 19th century is a history of children's rights. According to him, the child has three rights regarding education and training:

The right of parents to protect the child, the right of society to teach the child their religion, morality, and the right of the child to learn them, the right of the state to teach the child their political views and the child to learn them. According to him, these rights are necessary to complement each other, not to eliminate each other. Emrullah Efendi says that after stating this, children have the right to education by any means and emphasizes that this should not be 
prevented in any way. For this reason, he defends the idea that primary education should also be free of compulsory education. The greatest innovation he brought to education was in this field, and he made primary education compulsory and general education schools free with a law he prepared (Ergin, 1977).

\subsection{Selim Sabit Efendi (1829-1911)}

He was born in 1829 in Vize. He is the son of farmer Mehmet Ağa. After completing his primary education in his hometown, he came to Istanbul. He continued his lectures in Fatih Mosque, who resided in Gazanfer Ağa Madrasa. He attended Darülmuallimin, the first male teacher training school of the Ottoman Empire, which was opened in 1848 in Istanbul and received a diploma from there in 1853. He was dismissed because of the word "hal" (deposition) in his work titled "Muhtasar Târih-i Osmâni (Short Ottoman History). After staying up to the ministry of Zühtü Pasha, he was retired. He died in Istanbul Saryer in January 1911. He was buried in the family cemetery next to Kaşgari Lodge in Eyüp (Akyüz, 2001; Koçer, 1991; Öztürk, 2005; Kayaoğlu, 2001).

Selim Sabit Efendi is our educational scientist during a constitutional period (1876-1908). He worked as an educational scientist and produced important works on education. After finishing the madrasa and teacher school in Istanbul, he went to Paris. After returning to his hometown, he worked as a teacher and writer. In an elementary school opened in the district of Süleymaniye in Istanbul, it was the first time he had ever used school supplies and teaching tools such as desks, calculators and maps, which were considered new and important at that time. In other words, it is the person who first used today's class order and brought it to the Ottoman Empire. His place in Turkish Education History is due to his work in three fields. These areas of work are as follows:

\section{$\checkmark \quad$ Innovation efforts undertaken as a pioneer in primary education}

$\checkmark$ To have written a guiding pedagogy for primary school teachers in their renovation efforts.

$\checkmark \quad$ Trying to save prospective teachers from madrasah mentality. He is in his work titled "Rehnümâ-yı Muallimîn", which is an important work in the field of teaching science and in our history of education- this book is the first teaching method book of the Sibyan Schools (General name given to primary education institutions in the Ottoman Empire). He guided teachers in the direction of western thinking.

His key views in the field of teaching science are:

$\checkmark$ Use of course materials in teaching activities.

$\checkmark \quad$ Using fairy tales in moral education.

$\checkmark$ Respecting the personality of the child in educational activities.

$\checkmark$ Teacher's being a guide in teaching. Having the student make the invention.

$\checkmark \quad$ Individual training in the early stages of education and social-group training in the 
later stages.

$\checkmark \quad$ Teaching an adult student to a lower level student group in teaching activities.

$\checkmark$ In today's sense, preschool and primary school teachers are more merciful, compassionate, patient, broad-hearted, egalitarian, do not bear grudges, do not accept privileges and have good morals.

$\checkmark$ Enabling students to speak and write Turkish well.

$\checkmark$ Scientific in teaching activities.

$\checkmark$ Processing master samples rather than multiple content.

$\checkmark$ Making the school a paradise for children and the lesson a source of joy (Akyüz, 2001; Koçer, 1991).

It influenced the Ottoman Empire, which was in the process of innovation in the field of education, our intellectuals and people related to education, who were naturally trying to keep up with the West. Many interdependent or independent innovations were made in order to open schools, train teachers and finally provide education according to Western methods (Akyüz, 2001; Koçer, 1991; Duman, 1991).

\subsection{Satı Bey (1880-1968)}

Sat1 Bey, who graduated from the Civil School, worked as a teacher for a while and worked in training services. Originally Arab, Satı Bey had Ottomanist views, not Turkic. However, he was respected and loved by Turkists for his work in the field of pedagogy (Akyüz, 1993).

According to Sat1 Bey, education is the development of all interests and abilities of a person in a way that will ensure the happiness of both himself and others. By giving priority to interests and abilities in education, he did not consider education according to religious resources as his predecessors did, but instead emphasized biological and other resources. This represents a turning point in the understanding of education. By strongly criticizing the rote learning-based method in schools, he advocated research instead, and applied and brought this method to bear on in schools. During this period, he gave importance to the education of fine arts, which was not emphasized too much, and implemented the curriculum of fine arts in the curricula of the schools. Considering all these developments, we can state the innovations that Sat1 Bey brought to education as follows: He gave importance to students' self-management and supervision. Thus, the beginning of self-government goes back to the period of constitutionalism. It was the first time that children were concerned with everyday events and applied the principles of "topicality" in teaching. Regarding daily events, he used a projector for the first time in teaching. He opened an "practice school" within the teacher school and made its program on his own. At the end of the implementation of each lesson, he started the tradition of having scientific discussions. He put the teacher school in boarding and ensured the teachers to keep watch at night. He organized a "Teachers Training School Congress" by gathering teachers school graduates at the school every year, by this means he made an evaluation of educational experiments and practices. He gave importance to 
environmental trips in education and for the first time he organized trips to historical places, factories and rural areas. He established a museum and a library within the school.

He made great efforts to include physical education, painting, handicraft and music lessons in the curriculums of Darülmuallimin and various schools and to improve the lessons. He strongly opposed the idea that anyone in the society could teach, and argued that teaching is a profession based on special skills. According to him, "failure to understand this reality is the biggest wound of our education". He argued against Emrullah Efendi's Tûba Tree Theory, that educational reform can be made similar to natural trees, and that education reform should be made from primary schools to higher education. Because if the primary education is poor, the child cannot be successful in the next education levels (Akyüz, 1993; Binbaşığlu, 1995). Thus, Satı Bey laid the foundations of the main activities seen in institutions that train teachers from time to time, and contributed to the creation of a good tradition in this regard.

\section{Discussion and Conclusion}

As a result of the research, the educational thinkers are generally in the direction of giving a holistic education to the child in which national and moral values as well as abilities are emphasized. According to this;

(1) Sâdi Shirazi gives importance to the education of children who enter the puberty period (due to the age of 10) and recommends that they be raised as having "knowledge", "skills" and "ingenuity" and by putting forward their judgement abilities. He emphasizes that children should be given to a good, compassionate and authoritative teacher in primary school, because the child will look like a teacher. It states that punishment and reward should also be restrained.

(2) Kınalızâde Ali Efendi also recommends an education based on our values, in which the abilities of the child are brought to the forefront because of the necessity of education in general with moral aspects. According to Kınalızâde Ali Efendi; the way to be a good person is possible with a good education. He emphasizes that moral people will be happy in the world and the hereafter. According to him, education has an important place in the training of people. His work, Ahlâk-1 Alaî, is the first Turkish ethics book and was taught in madrasahs until the Republic period.

(3) Nâbi wrote a book of advice called Hayriyye, and by adopting his advice taught in schools until the Republic period. Nâbi recommended raising a religious type of people who are devoted to worship and stand aside and submit to their fate instead of the warrior Turkish type. In this education system, as the child will stay away from thinking, questioning and researching so as this is not a method recommended by educators, it has not been respected after the Republic.

(4) Ali Suavî prefers an active person equipped with essential knowledge, rather than a passive person equipped with a lot of unnecessary information. In other words, it is the opposite of the system Nâbi recommends. According to him, the education system should be in a way that reveals children's abilities based on their national and spiritual feelings. 
(5) According to Emrullah Efendi, children and young people should be developed morally and mentally in accordance with constitutionalism. He put forward the Tuba Tree Theory and advocated that innovation should start with higher education for the development of the country.

(6) Selim Sabit Efendi emphasizes the following six items for the full realization of education:

$\checkmark \quad$ Class size should not exceed 8 students as much as possible.

$\checkmark$ Students' individual differences should definitely be taken into account.

$\checkmark \quad$ While lecturing to students, different methods should be applied in view of the above feature.

$\checkmark$ Perception capabilities of the student should be taken into consideration while creating branches.

$\checkmark$ Any new thing that is given to the student must be presented on the board.

$\checkmark$ The directions in which any two similar things differ from each other must be explained.

$\checkmark \quad$ Students should not be left unattended as much as possible, they are advised to do writing and calculus work whenever they are free.

These are original methods that are based on logic in an environment where a random education is given, and are thought to bring the education to its real goal. Apart from these factors, another remarkable situation is that Selim Sabit Efendi imposes certain criteria in order to have the teaching profession. The most important of these is that the age of the teacher must be over 25. Teachers should speak Turkish well, have sufficient knowledge about simple mathematics, history, and geography. In addition, since teachers are exemplary people, they should act in accordance with the general etiquette of the society. In addition to these, Selim Sabit Efendi emphasized the rules that students should also obey. According to him, the behavior of all students in the school, in the lessons, during break time, their absence, reasons for not attending school, etc. should be followed carefully.

(7) Sat1 Bey is not a Turkist but an Ottomanist, since he is of Arab origin. But he was an educator loved by Turkists because he brought many innovations in the education system. He opposed the Tuba Tree Theory and argued that education reform should begin from primary education. Like other thinkers, Sat1 Bey emphasized biological and other resources, not religious resources, in children's education. It recommended that the child's abilities should be emphasized and an education system according to the child should be implemented.

As a result, while raising our children, the suggestions of thinkers who can be regarded as an authority in the Ottoman Empire are to entrust them to good teachers, provide them with the skills that may be needed in life as well as our national and spiritual values, skills that may be needed in life and educate them on a moral basis in line with their abilities. Instead of forcing our children to do jobs and skills they cannot do, education policies should be followed that 
will improve their jobs and skills. This research will be useful in terms of guiding academic research on educational policies before and after the Ottoman period. By using this study, researchers can research the Republican Era educators, their views, and the educational policies of the state.

\section{Findings and Comments}

In this article, in which we discuss the general views of the major educators in the Ottoman Empire, we understand that the educators agree on moral education and that discipline, punishment and reward should be in a certain amount. In addition, these educators state that the importance of encouraging the child to research should be given an education without preparation. These educators also the necessity of revealing the abilities and talents of the child and the preparation of an education system according to the child, as well as the need for the developed education system of the west to be taken as an example.

While almost all of these educators we examined focused on the education of the teacher and the student, Selim Sabit Efendi focused on the physical characteristics of both the teacher and the student and the educational environment. Selim Sabit Efendi is the first person who brought today's classroom environment (board, classroom cabinet, maps, desk, table, etc.) to the Ottoman Empire for the first time. Westernization in education started with Selim Sabit Efendi for the first time. This is very important as it is one of the first steps in the transition from madrasa to school in the Ottoman Empire.

\section{References}

Akyüz, Y. (1993). Türk Eğitim Tarihi (4th ed.), Istanbul, Turkey.

Akyüz, Y. (2001). Türk Eğitim Tarihi (8th ed., pp. 132-205). Istanbul, Alfa Yayınları.

Binbaşığlu, C. (1995). Okullarda Öğretim Sorunları. Ankara: Eğit-Der Yayınları.

Çelik, H. (1994). Ali Suavî ve Dönemi. İstanbul, Turkey.

Çubukçu, İ. A. (1991). Türk Düşünce Tarihinde Felsefe Hareketleri. Ankara, Turkey.

Duman, T. (1991). Türkiye'de Orta Öğretime Öğretmen Yetiştirme (1st ed., pp. 11-15). Milli Eğitim Bakanlığı Yayınları, Istanbul, Turkey.

Ergin, O. (1977). Türkiye Maarif Tarihi (Vol. 3-4). Istanbul, Turkey.

Ergün, M. (1987). Satı Bey, Hayatı ve Türk Eğitimine Hizmetleri. Inönü Üniversitesi Sosyal Bilimler Dergisi (Vol. I, p. 4). Malatya, Turkey.

Esen, N. (1991). Türk Romanında Aile Kurumu. Ankara, Turkey.

Forster, N. (1995).The Analysis of Company Documentation. In C. Cassel \& G. Symon (Eds.), Qualitative Methods in Organizational Research: A practical guide. London: Sage.

Kaplan, M. (1995). Türk Edebiyatı Üzerinde Araştırmalar I (3rd ed.). İstanbul, Turkey. 


\section{Macrothink}

Kayaoğlu, T. (2001). (Haz.) Maârif-i Umûmiye Nezâreti Târihçe-i Teşkilat ve İcraatı-XIX. Asır Osmanlı Maarif Tarihi (p. 111, p. 133, p. 160). Mahmud Cevat Ibnü’ş Şeyh Nâfi, Yeni Türkiye Yayınları, Ankara, Turkey.

Kınalızâde, A. E. (n.d.a). Ahlâk, Ahlâk-1 Alâ'î. In H. Algül (Ed.), Tercüman 1001 Temel Eser.

Kınalızâde, A. E. (n.d.b). Devlet ve Aile Ahlâkı. In A. Kahraman (Ed.), Tercüman 1001 Temel Eser.

Koçer, H. A. (1991). Türkiye'de Modern Eğitimin Doğuşu ve Gelișimi (1773-1923) (2nd ed., pp. 5-164). Milli Eğitim Bakanlığı Yayınları, Istanbul, Turkey.

Kurnaz, C. (1984). Muallim Naci ve Osmanlı Şairleri. İstanbul, Turkey.

Mengi, M. (1991). Divan Şiirinde Hikemî Tarzın Büyük Temsilcisi NÂBÎ. Ankara, Turkey.

Öztürk, C. (2005). Türkiye'de Dünden Bugüne Öğretmen Yetiștiren Kurumlar (1st ed., pp. 9-58). Milli Eğitim Bakanlığı Yayınları, Istanbul, Turkey.

Öztürk, H. (1991). Kınalızâde Ali Çelebi'de Aile. Ankara, Turkey.

Sâdi, Ş. (1975). In K. R. Bilge (Ed.), Bostan ve Gülistan (10th ed.). Istanbul, Turkey.

Ülken, H. Z. (1992). Türkiye'de Çağdaş Düşünce Tarihi (3rd ed.). Istanbul, Turkey.

Yıldırım, A. \& Şimşek, H. (2011). Sosyal Bilimlerde Nitel Araştırma Yöntemleri (8th ed., p. 188). Seçkin Yayıncılık, Istanbul, Turkey.

\section{Copyright Disclaimer}

Copyright for this article is retained by the author(s), with first publication rights granted to the journal.

This is an open-access article distributed under the terms and conditions of the Creative Commons Attribution license (http://creativecommons.org/licenses/by/3.0/). 